\title{
Assessment of Knowledge, Attitude and Practice Regarding Breast Self-Examination Among Female Students in Debre Birhan University, North Shewa Ethiopia
}

\author{
Tesfa Mengie*, Andargie Yifru, Asfaw Fikre, Woldetsadik Niguse, Damen Demsie, Meseret Ekubay \\ Department of Nursing, College of Medicine and Health Science, Debre Birhan University, North Shewa, Ethiopia \\ Email address: \\ mengie.tesfa@yahoo.com (T. Mengie) \\ ${ }^{*}$ Corresponding author \\ To cite this article: \\ Tesfa Mengie, Andargie Yifru, Asfaw Fikre, Woldetsadik Niguse, Damen Demsie, Meseret Ekubay. Assessment of Knowledge, Attitude and \\ Practice Regarding Breast Self-Examination Among Female Students in Debre Birhan University, North Shewa Ethiopia. American Journal \\ of Clinical and Experimental Medicine. Vol. 8, No. 3, 2020, pp. 42-48. doi: 10.11648/j.ajcem.20200803.13
}

Received: May 17, 2020; Accepted: June 1, 2020; Published: June 16, 2020

\begin{abstract}
Breast Self-Examination is a method where by women examines their breasts regularly to detect any abnormal swelling or lumps in order to seek prompt medical attention. Knowledge, attitude and practice towards breast self-examination is important among females for screening, early detection and diagnosis of breast Cancer. Objective of the Study was to determine knowledge, attitude and practice regarding breast self-examination among female students in Debre Birhan University, 2013. Institutional based cross sectional study design was used among 374 students. Simple random sampling was used. Data was entered onto Epi Data version 3.01, exported to and analyzed by SPSS version 20 statistical software. From the total of 367 participants $170(46.3 \%)$ had heard about breast self-examination while most $197(53.7 \%)$ had never heard about it. The commonest source of information about breast self-examination was media $118(69.4 \%)$. Majority 273 (74.4\%) of the respondents had poor knowledge, most 289 (78.7\%) of the respondents had negative attitude and majority 281 (76.6\%) of the respondents had poor practice of breast self-examination. Practices have associations with academic year, department and media exposure. Generally, in this study knowledge, attitude and practice of breast self-examination was unsatisfactory. Poor practice is an indication of poor knowledge and negative attitude. Programs should be strengthened about breast selfexamination and its importance for early detection of breast cancer.
\end{abstract}

Keywords: Knowledge, Attitude, Practice, University Students, Breast Self-Examination

\section{Introduction}

Breast self-examination is one of the vital screening techniques for early detection of breast lumps, most especially cancer of the breast. Medical advances have shown that onethird of all cancers are preventable and a further one third, if diagnosed sufficiently early, is potentially curable. This observation demands that cancer control should be of increasing priority in the health care programme of developing countries [1]. One potentially important strategy in reducing breast cancer mortality is the use of screening to achieve earlier detection of cancer [2]. Despite the advent of modern screening methods, more than $90 \%$ of cases of cancers of the breast are detected by women themselves using breast self-examination [3].

Worldwide breast cancer has been reported as the most common cancer in women and the second leading cause of death [4]. The study conducted on knowledge, attitudes, regarding breast cancer detection practices found that out of 57 south Asian women, $12 \%$ of the participants practiced breast self-examination monthly. But majority (54\%) of women has lack of knowledge about breast cancer [5]. in Terengganu approximately one-third of students reported performing breast self-examination monthly [6]. Studies in Nigeria indicate that the attitudes of breast self-examination, only $18.3 \%$ respondents care to seek for knowledge about breast self-examination, others $81.7 \%$ did not bother to know more on breast self-examination, Three hundred (42.8\%) respondents believed that it is necessary to perform breast self-examination [7]. Breast self-examination is an important method to detect breast cancer early and little is known about 
knowledge, attitude and practice of breast self-examination among Ethiopian University students.

\section{Methodology}

\subsection{Study Area and Period}

The study was conducted in DBU. DBU is one of the universities in Ethiopia which is found in Amhara regional state. Debre Birhan town is the capital city of North shoa zone, which is far $130 \mathrm{Km}$ from A. A and $695 \mathrm{k} . \mathrm{m}$. from Bahirdar. The university was established in the year June 1999 E. C. currently there are 8889 students learning in the university within 2 colleges, 3 schools and 2 institution with their respective departments. Among 8889 students 2981 are regular female students. The study was conducted in DBU starting from January -June 2013.

\subsection{Study Design}

An institutional based cross sectional study design was conducted to assess knowledge, attitude and practice of BSE among DBU regular female students.

\subsection{Source Population}

The source population was all female students in Debre Birhan University.

\subsection{Study Population}

The study population was all female students in selected departments

\subsection{Inclusion Criteria}

Female students who were willing to participate.

\subsection{Exclusion Criteria}

Female students who faced vision problem and seriously ill female students.

\subsection{Sample Size Determination and Sampling Technique}

\subsubsection{Sample Size Determination}

The sample size was determined by using a formula for estimating a single population proportion and assuming a confidence interval of $95 \%$ and marginal error of $5 \%$. By taking $50 \%$, the proportion was 0.5 or $50 \%$ and the sample size was calculated using the following formula;

$$
\mathrm{n}=\mathrm{z}_{\mathrm{a}}^{2} \mathrm{pq} / \mathrm{d}^{2}
$$

Where $\mathrm{n}=$ the minimum sample size required

$\mathrm{Z}=\mathrm{A}$ standard score corresponding to $95 \%$ certainty and is thus equal to 1.96

$\mathrm{P}=$ an estimation of the prevalent rate for the student

$\mathrm{q}=1-0.5=0.5$

$\mathrm{d}=$ the margin of error tolerated $(5 \%)(0.05)$

$\mathrm{n}=(1.96)^{2} \times(0.5) \times(0.5) /(0.05)^{2}=384$

But the total population was less than 10,000 as the information obtained from DBU registrar office, so we used smaller sample size to calculate the actual size.

$$
\mathrm{nf}=\mathrm{n} /(1+\mathrm{n} / \mathrm{N})=384 / 1+384 / 2981=340
$$

Non response rate $(10 \%)$ of sample size was added. (Ten percent of sample size $=340.179 \times 10 \%=34.0179)$ and the total study unit (sample) required $=340.179+34.0179=374$.

\subsubsection{Sampling Technique}

The type of sampling that we were used was simple random sampling technique. We used all faculties and we selected sample departments by simple random sampling from different years proportionally. By taking all female students who were included in the study from each department using proportional allocation of the sample size was made for each department by using the following formula.

$\mathrm{ni}=\mathrm{Ni} \times \mathrm{n} / \mathrm{N}$

Where ni=total sample size determined in each department $\mathrm{Ni}=$ total number of students in each department

$\mathrm{N}=$ total number of DBU regular female students $\mathrm{n}=$ total sample size of the study population

\subsection{Data Collection Method}

We adopted self-administered questionnaire in English and translated to Amharic language and then back to English to check for its consistency. The questionnaire was used to collect information on the variables such as attitude, knowledge, practice and Socio-demographic characteristics. The data was collected from Debre Birhan University female students by distributing questionnaire to the selected sample and then data collectors collected questionnaire after being filled by respondents.

\subsection{Study Variables}

Dependent variable

Knowledge, attitude and practice about BSE. Independent variable

Age, marital status, ethnicity, religion, department, academic year, media exposure

\section{Operational Definition}

Knowledge $=$ information that a person get from experience and education, and a person is said to have good knowledge if she scored more than or equal to 75 percent of the expected answers, fair knowledge if she scored 50 to 75 percent of the expected answers, and poor knowledge if she scored less than 50 percent of the expected answers.

Attitude=a way of thinking, feeling about BSE, and a person is said to have positive attitude if she scored more than or equal to 70 percent of the expected answers and negative attitude if she scored less than 70 percent of the expected answers.

Practice $=$ the action of performing BSE, and a person is said to have good practice if she scored more than or equal to 
75 percent of the expected answers, fair practice if she scored 50 to 75 percent of the expected answers, and poor practice if she scored less than 50 percent of the expected answers.

\subsection{Data Management and Analysis}

The data was entered to Epi Data v. 3.0 \& analyzed by SPSS V. 20 then the result was interpreted and presented by using tables, bar graph, pie chart, and chi square test to determine the significance of the association.

\subsection{Data Quality Assurance}

To assure the validity and reliability of the questionnaire, each item of data collection instrument was being analyzed and made ready prior to data collection. During data collection time continuous ongoing monitoring, supervision and random cross checking was carried out by principal investigator for being sure of the completeness of each questionnaire. Finally the completeness of the questionnaires was double checked before data used.

\subsection{Ethical Consideration}

The proposal was submitted for ethical review committee of the faculty, and then principal investigators were obtained permission from college of medicine and health science before the process of data collection. The purpose of the study was briefly explained for the respondents and verbal informed consent was obtained from the respondents and explained that the confidentiality of the information collected was kept anonymous.

\section{Result}

\subsection{Socio-demographic Characteristics}

In the analysis of KAP towards breast self-examination in DBU regular female students from 374 respondents, the respondent rate was $367(98.1 \%)$ and the non-response rate was $7(1.9 \%)$. The majority of the respondents $249(67.8 \%)$ were in the age group of 20-24 years and the mean and modal age was 21 and 20 years respectively. Most of the respondents 276 (75.2\%) were orthodox Christian followers. From 367 participants the highest proportion of the respondents $308(83.9 \%)$ were unmarried.

Table 1. Socio Demographics Characteristics of Regular Female Students in DBU, June 2013.

\begin{tabular}{llll}
\hline & Variable & Frequency & Percent (\%) \\
\hline \multirow{4}{*}{ age } & $15-19$ & 72 & 19.6 \\
& $20-24$ & 249 & 67.8 \\
\multirow{5}{*}{ Ethnicity } & $25-29$ & 46 & 12.6 \\
& Amhara & 186 & 50.7 \\
& Tigre & 90 & 24.5 \\
& Oromo & 41 & 11.2 \\
& Others & 50 & 13.6 \\
religion & Orthodox & 276 & 75.2 \\
& Muslim & 35 & 9.5 \\
& Catholic & 11 & 3.0 \\
& Protestant & 43 & 11.7 \\
& Others & 2 & 0.6 \\
\hline
\end{tabular}

\begin{tabular}{llll}
\hline & Variable & Frequency & Percent (\%) \\
\hline \multirow{4}{*}{ Marital status } & Married & 55 & 15 \\
& Unmarried & 308 & 83.9 \\
& Divorced & 4 & 1.1 \\
& Nursing & 60 & 16.3 \\
& Civil & 146 & 39.8 \\
& IT & 30 & 8.2 \\
Department & Chemistry & 35 & 9.5 \\
& Animal & 10 & 2.7 \\
& Psychology & 16 & 4.4 \\
& Management & 70 & 19.1 \\
year & $1^{\text {st }}$ & 135 & 36.8 \\
& $2^{\text {nd }}$ & 99 & 27.0 \\
& $3^{\text {rd }}$ & 114 & 31.1 \\
& $4^{\text {th }}$ & 19 & 5.1 \\
\hline
\end{tabular}

\subsection{Assessment of Knowledge of BSE}

Results regarding on knowledge of BSE showed that out of 367 participants most 197 (53.7\%) had never heard about BSE while 170 (46.3\%) had heard about it. The commonest source of information about BSE was media 118 (69.4\%). Majority of the respondents $119(70.0 \%)$ said that BSE is important to detect Breast cancer early and most $74(43 \%)$ of the participants said that BSE should be started at the age of $>19$ years. on frequency of practicing BSE high proportion of the respondents $72(42.4 \%)$ said that it should be done daily followed by 58 (34.1\%) monthly. Majority 76 (41.2\%) of the of study subject agree that BSE should be practiced immediately after menstrual period, $106(62.4 \%)$ of the respondents said that it should be done in standing position and in front of the mirror.

Table 2. Knowledge of Regular Female Students in DBU, Ethiopia, June 2013.

\begin{tabular}{|c|c|c|c|}
\hline & Variable & Frequency & $\begin{array}{l}\text { Percent } \\
(\%)\end{array}$ \\
\hline \multirow{2}{*}{ Heard about BSE } & Yes & 170 & 46.3 \\
\hline & No & 197 & 53.7 \\
\hline \multirow{4}{*}{$\begin{array}{l}\text { Importance of BSE } \\
\text { for early detection } \\
\text { of Breast cancer }\end{array}$} & Yes & 119 & 70.0 \\
\hline & No & 41 & 24.1 \\
\hline & Don't know & 10 & 5.9 \\
\hline & Females & 113 & 66.5 \\
\hline \multirow{3}{*}{$\begin{array}{l}\text { Primarily beneficial } \\
\text { by BSE }\end{array}$} & Males & 9 & 5.3 \\
\hline & Family & 16 & 9.4 \\
\hline & Community & 32 & 18.8 \\
\hline \multirow{4}{*}{$\begin{array}{l}\text { Year of starting } \\
\text { BSE }\end{array}$} & $<19$ years & 43 & 25.3 \\
\hline & 19years & 53 & 31.2 \\
\hline & $>19$ years & 74 & 43.5 \\
\hline & Daily & 72 & 42.4 \\
\hline \multirow{3}{*}{$\begin{array}{l}\text { Frequency of doing } \\
\text { BSE }\end{array}$} & Weakly & 31 & 18.2 \\
\hline & Monthly & 58 & 34.1 \\
\hline & Yearly & 9 & 5.3 \\
\hline \multirow{4}{*}{ Time of doing BSE } & Before menstrual period & 50 & 29.4 \\
\hline & During menstrual period & 34 & 20 \\
\hline & $\begin{array}{l}\text { Soon after menstrual } \\
\text { period }\end{array}$ & 70 & 41.2 \\
\hline & Others & 16 & 9.4 \\
\hline \multirow{3}{*}{$\begin{array}{l}\text { Posture of doing } \\
\text { BSE }\end{array}$} & Lying & 56 & 32.9 \\
\hline & Standing & 106 & 62.4 \\
\hline & Other & 8 & 4.7 \\
\hline \multirow{4}{*}{ Place of doing BSE } & In front of mirror & 106 & 62.4 \\
\hline & In bed & 38 & 22.3 \\
\hline & In the bath room & 20 & 11.8 \\
\hline & Others & 6 & 3.5 \\
\hline
\end{tabular}




\begin{tabular}{llll}
\hline & Variable & Frequency & $\begin{array}{l}\text { Percent } \\
\text { (\%) }\end{array}$ \\
\hline & Lump & 106 & 28.9 \\
Symptoms to look & Change in size of breast & 62 & 16.9 \\
for during BSE & Nipple discharge & 60 & 16.4 \\
& Others & 71 & 19.3 \\
& Don't know & 68 & 18.5 \\
\hline
\end{tabular}

\subsection{Assessments of Attitude Towards BSE}

From 170 (46.3\%) participants, which were heard BSE, 92 (54.1\%) had negative attitude while $78(45.9 \%)$ had positive attitude towards BSE. students who have Interest to know more about BSE are 158 (92.9\%), who have not are 12
$(7.1 \%)$.

\subsection{Assessment of Practice of BSE}

From 170, which were heard BSE, 99 (58.2\%) were practiced BSE. Most of the respondents 44 (44.4\%) started doing BSE at the age of $>19$ years and majority of them 68 $(68.7 \%)$ done BSE monthly. Forty three $(43.4 \%)$ of those who did so examined their breast before menstruation and 75 (75.8) done BSE in front of mirror. The major barrier to do BSE was embarrassment $43(43.4 \%)$. Most of the respondents $41(41.4 \%)$ who practiced BSE look for lump while practicing BSE.

Table 3. Practice of DBU Regular Female Students in Ethiopia, June 2013.

\begin{tabular}{|c|c|c|c|}
\hline & Variable & frequency & Percent (\%) \\
\hline \multirow{3}{*}{ Done BSE before } & Yes & 99 & 58.2 \\
\hline & No & 71 & 41.8 \\
\hline & $<19$ years & 13 & 13.2 \\
\hline \multirow[t]{2}{*}{ Age of starting BSE } & 19 years & 42 & 42.4 \\
\hline & $>19$ years & 44 & 44.4 \\
\hline \multirow[b]{2}{*}{ Frequency of doing BSE } & 6 month & 2 & 2 \\
\hline & Monthly & 68 & 68.7 \\
\hline \multirow{4}{*}{ Time of doing BSE } & Before menstrual period & 43 & 43.4 \\
\hline & During menstrual period & 16 & 16.2 \\
\hline & Soon after menstrual period & 35 & 35.4 \\
\hline & Others & 5 & 5 \\
\hline \multirow{3}{*}{ Barriers faced to practice BSE } & Worry about breast cancer & 39 & 39.4 \\
\hline & Embarrassment & 43 & 43.4 \\
\hline & Unfavorable attitude & 15 & 15.2 \\
\hline \multirow{3}{*}{ Symptoms observed while doing BSE } & Large size of the breast & 35 & 35.4 \\
\hline & Pain & 20 & 20.2 \\
\hline & Others & 3 & 3 \\
\hline
\end{tabular}

Table 4. Association of Practice with Socio-Demographic Characteristics and previous media exposure.

\begin{tabular}{|c|c|c|c|c|c|c|c|}
\hline \multirow{2}{*}{ S. No. } & \multirow{2}{*}{ Variables } & \multicolumn{6}{|l|}{ Practice } \\
\hline & & Yes (expected) & No (expected) & Total & DF & $\mathbf{X}^{2}$ & p-value \\
\hline \multirow[t]{5}{*}{1} & Age & & & & & & \\
\hline & $15-19$ & 32 (19) & $40(53)$ & 72 & 2 & 15.023 & 0.0005 \\
\hline & $20-24$ & $55(67)$ & $194(182)$ & 249 & & & \\
\hline & $25-29$ & $12(12)$ & $34(34)$ & 46 & & & \\
\hline & Total & 99 & 268 & 367 & & & \\
\hline \multirow[t]{5}{*}{2} & Year & & & & & & \\
\hline & Second & $19(27)$ & $80(72)$ & 99 & & & \\
\hline & Third & $39(31)$ & $75(83)$ & 114 & & & \\
\hline & Fourth & $18(5)$ & $1(14)$ & 19 & & & \\
\hline & Total & 99 & 268 & 367 & & & \\
\hline \multirow[t]{8}{*}{3} & Department & & & & & & \\
\hline & Nursing & $45(16)$ & $15(44)$ & 60 & 6 & 112.64 & 0.0 \\
\hline & Chemistry & $16(9)$ & $19(26)$ & 35 & & & \\
\hline & Management & $5(19)$ & $65(51)$ & 70 & & & \\
\hline & Animal sc. & $1(3)$ & $9(7)$ & 10 & & & \\
\hline & Civil eng. & $18(39)$ & $128(106)$ & 146 & & & \\
\hline & Psychology & $7(5)$ & $9(12)$ & 16 & & & \\
\hline & Total & 99 & 268 & 367 & & & \\
\hline \multirow[t]{4}{*}{4} & Heard of BSE & & & & & & \\
\hline & Yes & $99(46)$ & $71(124)$ & 170 & 1 & 132.25 & 0.0 \\
\hline & No & $0(26)$ & $197(144)$ & 197 & & & \\
\hline & Total & 99 & 268 & 367 & & & \\
\hline
\end{tabular}

$\Rightarrow \mathrm{DF}=$ degree of freedom; $\mathrm{x} 2=$ chi-square; significance level $=0.05$. 
As we have seen from table five practice of BSE had association with age, academic year, and department, and hearing about BSE since p-value is less than 0.05 (significance level).

Table 5. Knowledge towards BSE and Department in DBU, June 2013.

\begin{tabular}{|c|c|c|c|}
\hline S. No. & Categories & Frequency & Percent (\%) \\
\hline \multirow[t]{5}{*}{1} & Psychology & & \\
\hline & Poor & 11 & 68.8 \\
\hline & Fair & 4 & 25 \\
\hline & Good & 1 & 6.2 \\
\hline & Total & 16 & 100 \\
\hline \multirow[t]{5}{*}{2} & Chemistry & & \\
\hline & Poor & 24 & 68.8 \\
\hline & Fair & 8 & 22.9 \\
\hline & Good & 3 & 8.3 \\
\hline & Total & 35 & 100 \\
\hline \multirow[t]{5}{*}{3} & Civil engineering & & \\
\hline & Poor & 123 & 84.2 \\
\hline & Fair & 14 & 9.6 \\
\hline & Good & 9 & 6.2 \\
\hline & Total & 146 & 100 \\
\hline \multirow[t]{5}{*}{4} & Management & & \\
\hline & Poor & 65 & 94.4 \\
\hline & Fair & 3 & 4.3 \\
\hline & Good & 1 & 1.3 \\
\hline & Total & 69 & 100 \\
\hline \multirow[t]{5}{*}{5} & IT & & \\
\hline & Poor & 24 & 80 \\
\hline & Fair & 5 & 16.7 \\
\hline & Good & 1 & 3.3 \\
\hline & Total & 30 & 100 \\
\hline \multirow[t]{5}{*}{6} & Nursing & & \\
\hline & Poor & 17 & 27.9 \\
\hline & Fair & 14 & 22.9 \\
\hline & Good & 30 & 49.2 \\
\hline & Total & 61 & 100 \\
\hline \multirow[t]{5}{*}{7} & Animal science & & \\
\hline & Poor & 9 & 90 \\
\hline & Fair & 1 & 10 \\
\hline & Good & 0 & 0 \\
\hline & Total & 10 & 100 \\
\hline
\end{tabular}

The above table shows that the effect of department on knowledge of BSE. From the total department the student who follow nursing program had more $30(49.2 \%)$ good knowledge than other department students. As we have seen academic year had effect on knowledge of BSE. Since fourth year students had more $(83.3 \%)$ knowledge of BSE than other academic year students.

The finding shows that the effect of department towards BSE. From the total department the student who follow nursing program had more positive attitude (40.9\%) than other department students.

Table 6. Attitudes towards BSE and Academic Year in DBU, June 2013.

\begin{tabular}{llll}
\hline S. No. & Categories & Frequency & Percent (\%) \\
\hline 1 & First year & & \\
& Negative & 106 & 77.4 \\
& Positive & 31 & 22.6 \\
& Total & 137 & 100 \\
2 & Second year & & \\
& Negative & 78 & 79.6 \\
\hline
\end{tabular}

\begin{tabular}{llll}
\hline S. No. & Categories & Frequency & Percent (\%) \\
\hline \multirow{4}{*}{3} & Positive & 20 & 20.4 \\
& Total & 98 & 100 \\
& Third year & & \\
& Negative & 94 & 83.2 \\
& Positive & 19 & 16.8 \\
4 & Total & 113 & 100 \\
& Fourth year & & \\
& Negative & 11 & 57.9 \\
& Positive & 8 & 42.1 \\
& Total & 19 & 100 \\
\hline
\end{tabular}

As we have seen from the above table academic year had effect on attitude of BSE. Since fourth year students had more $8(42.1 \%)$ positive attitude of BSE than other academic year students.

Table 7. Practice of BSE and Department in DBU, June 2013.

\begin{tabular}{|c|c|c|c|}
\hline S. No. & Categories & Frequency & Percent (\%) \\
\hline \multirow[t]{5}{*}{1} & Psychology & & \\
\hline & Poor & 4 & 50 \\
\hline & Fair & 3 & 37.5 \\
\hline & Good & 1 & 12.5 \\
\hline & Total & 8 & 100 \\
\hline \multirow[t]{5}{*}{2} & Chemistry & & \\
\hline & Poor & 12 & 50 \\
\hline & Fair & 10 & 41.7 \\
\hline & Good & 2 & 8.3 \\
\hline & Total & 24 & 100 \\
\hline \multirow[t]{5}{*}{3} & Civil engineering & & \\
\hline & Poor & 42 & 70 \\
\hline & Fair & 12 & 20 \\
\hline & Good & 6 & 10 \\
\hline & Total & 60 & 100 \\
\hline \multirow[t]{5}{*}{4} & Management & & \\
\hline & Poor & 8 & 72.7 \\
\hline & Fair & 2 & 18.2 \\
\hline & Good & 1 & 9.1 \\
\hline & Total & 11 & 100 \\
\hline \multirow[t]{5}{*}{5} & IT & & \\
\hline & Poor & 8 & 66.7 \\
\hline & Fair & 4 & 33.3 \\
\hline & Good & 0 & 0 \\
\hline & Total & 12 & 100 \\
\hline \multirow[t]{5}{*}{6} & Nursing & & \\
\hline & Poor & 9 & 17.3 \\
\hline & Fair & 18 & 34.6 \\
\hline & Good & 25 & 48.1 \\
\hline & Total & 52 & 100 \\
\hline \multirow[t]{5}{*}{7} & Animal science & & \\
\hline & Poor & 1 & 33.3 \\
\hline & Fair & 1 & 33.3 \\
\hline & Good & 1 & 33.4 \\
\hline & Total & 3 & 100 \\
\hline
\end{tabular}

The above table shows that the effect of department on practice of BSE. From the total department the student who follow nursing program had good practice 25 (48.1\%) more than other department students. Academic year had effect on practice of BSE. Since fourth year students had good practice $8(66.7 \%)$ of BSE more than other academic year students 


\section{Discussion}

In this study majority $197(53.7 \%)$ of the respondents had never heard while $170(46.3 \%)$ of the respondents had ever heard about BSE. This finding was similar with slight difference in percentage with findings of the study done in Jeddah, Saudi Arabia where $60.4 \%$ of the respondents had never heard while $39.6 \%$ of the respondents ever heard about BSE [20]. This difference in percentage can be due to difference in sample size. But it is not consistent with findings reported from a study in Awka Anambra state, in Nigeria where $4.4 \%$ of the respondents had ever heard while $95.6 \%$ of the respondents had ever heard of BSE (1). This discrepancy can be due to age difference in the study participants. With respect to knowledge of respondents about frequency and appropriate time to practice BSE, only $15.8 \%$ and $19 \%$ knew the correct frequency and timing respectively in this study. This finding agreed with the study done in Jeddah, Saudi Arabia where only $14.4 \%$ and $17 \%$ knew the correct frequency and timing respectively [20]. This can be due to the information gap on frequency and timing of BSE.

In this study the major source of information about BSE was electronic media $118(32.2 \%)$ while the least source of information was family $12(3.3 \%)$. Similar finding was reported with slight difference in percentage from study done in Awka Anambra state, of Nigeria where majority of the respondent's first source of information was electronic media $(38.8 \%)$, whereas the least source of information $(4.0 \%)$ was family [1]. This slight difference can be because of difference in distribution of electronic media and difference in family life discussion in both countries. On the assessment of knowledge of participants of this study about frequency of practicing BSE, $58(15.8 \%)$ of the study participants said that BSE should be practiced monthly while $9(2.5 \%)$ said yearly. This is not similar with findings reported from Port Hart Court, in Nigeria where most of the respondents (42.7\%) said that BSE should be practiced monthly while $(6.7 \%)$ said yearly [21]. This difference might be as a result of inadequate health education about BSE in this study area.

On the assessment of knowledge of respondents on symptoms to look for during BSE, among respondents who had heard of BSE most 106 (28.9\%) said that one should look for presence of lump in the breast, $62(16.9 \%)$ change in the size of the breast, $60(16.4 \%)$ nipple discharge and 71 $(19.3 \%)$ others during BSE. This is not similar with the study reported in Awka Anambra state in Nigeria where most 447 $(63.8 \%)$ knew presence of lump in the breast, $272(38.9 \%)$ changes in the size of the breast, 262 (37.4\%) nipple discharge and 267 (38.1\%) others during BSE [1]. This is can be due to insufficient health education on breast cancer in this study area and due to high concern of breast cancer in Nigeria. This research reveals that majority of the respondents had poor knowledge 273 (74.4\%) followed by, fair $49(13.4 \%)$ and good 45 (12.2\%). This is not agreed with the research done in Addis Ababa University in 2010 in Ethiopia where over $90 \%$ of the respondents had good knowledge about BSE [21]. This can be due to the information gap and low concern of BSE in DBU.

In this study majority $289(78.7 \%)$ of the respondents had negative attitude while $78(21.3 \%)$ had positive attitude towards BSE. This is not consistent with the study done in Jeddah, Saudi Arabia where $82.4 \%$ of the respondents had positive attitude and $17.6 \%$ had negative attitude towards BSE [20]. This might be due to poor consideration and awareness of the importance of BSE in this study area and population.

This study reveals that majority 268 (73\%) of the respondents did not perform BSE whereas 99 (27\%) of the respondents performed BSE. This is not consistent with the study done in Shiraz, Southern Iran, where $46.7 \%$ of the participants did not perform BSE but majority (53.3\%) had performed BSE [18]. Also it is not agreed with the study done in Awka Anambra state, in Nigeria where majority $(54.8 \%)$ of the respondents had done BSE [1]. This discrepancy might be as a result of insufficient health education on breast cancer in this study area and due to high concern of breast cancer in Nigeria and Southern Iran.

Among the study participants who had practiced BSE, 58 $(16 \%)$ used the correct frequency. This is much lower than the study done in Awka Anambra state, in Nigeria where 115 (71.8\%) of the respondents who were doing BSE did it once monthly (1) which is the correct and recommended frequency of BSE. This great difference might be resulted from high consideration and attention of BSE in Awka Anambra state, in Nigeria. On the assessment of barriers to practice BSE 39 $(10.6 \%)$ of the respondents did not practiced BSE for fear of being positive for cancer. This is not agreed with the study done in Shiraz, Southern Iran, where 66 (22\%) did not practice BSE for fear of being positive for cancer (19). This difference can be as a result of difference in sample size. From those studied samples $41(11.1 \%)$ found lump when they examined their breast. This is not consistent with the study done in Shiraz, Southern Iran, where 9 (5.6\%) found lump during BSE [18]. This discrepancy can be due to unknown reason. From the total population studied most 281 $(76.6 \%)$ of the respondents had poor practice followed by fair $50(13.6 \%)$ and good $36(9.8 \%)$. This is not consistent with the study done in Addis Ababa University in 2010 in Ethiopia where only $27 \%$ had good practice [22]. This discrepancy can be due to the site where the study was conducted

\section{Conclusion}

Majority of the students had poor knowledge, negative attitude and poor practice regarding breast self-examination. Education on breast self-examination is needed to address the problem. Practices have associations with academic year, department and media exposure with p-value of 0.0 and also have association with age with $\mathrm{p}$ value of 0.0005 .

\section{Acknowledgements}

We would like to express our gratitude to our advisor Meseret Ekubay (Bsc, MSC) for her valuable guidance and 
comment in the preparation of this research. Our appreciation and thanks also extends to participants and data collectors. Finally we would like to express our deepest gratitude for Abdurrahman Mohammed (Bsc, MSC) for giving us the source for our research.

\section{References}

[1] F. O. Kayode, T. M. Akande, G. K. Osagbmi Department of Epidemiology and Community Health, University of Ilorin, Nigeria, European Journal of Scientific Research, Vol 10, No $3,2005$.

[2] World Health Organization, Conquering Suffering, Enriching Humanity; The World Health Report. WHO Geneva, 1997: 22-39.

[3] P. Christmas, S. Nicholas "Don't take a chance". A public campaign to encourage the early reporting of breast symptoms; Health Education J, 1982, 41: 6-68.

[4] D. M. Parkin, C. S. Muir, S. L. Whelan et al Cancer incidence in five continents. ARC Scientific Publication No. 120 IARC Lyon, 1992: 13-16.

[5] Lewis, collier, Heitkemper. Medical Surgical Nursing. USA: MOSBY; 1996.

[6] URL: http://myoclinic.com/healthy/. Assessed on December 20/12/2012.

[7] Arlene L, Suzanne E. Luckmann's Medical Surgical Book. Philadelphia: W. B. Saunders 1; 1996. 8. Spitt. M. Morgan D: Women remain confused about breast cancer. Pubmed, abstract/publisher full text/pub med central full text. BMJ 1999, 318: 600 .

[8] Parkin DM, Bray F, Ferlay J, Pisani P: Global cancer spastics CA cancer. Pub med abstract/publisher full text. Jilin 2005, 55 (2): 74-108.

[9] Choudhary UK, Srivastava R, Fitch MI, Breast Cancer Detection practices of South Asian Women, knowledge, Attitudes and Beliefs, Oncology Nursing Forum,(1998), Vol$25(10)$.

[10] Budden L, Student Nurses Breast Self-Examination health beliefs, attitude, knowledge and performance during the first year of a pre-registration degree program, Journal of Cancer Nursing, 1999, Dec, Vol-22 (6).

[11] European Journal of Social Sciences, Department of
Epidemiology \& Community Health, College of Health Sciences University Of Ilorin, 2009, Volume - 7 (3).

[12] Hemlatha, E, A study to assess the knowledge and attitude towards Breast Self-Examination Among College girl at selected college, Tamilnadu, Nightingale Nursing Times, Jan 2008, Vol. 3 (10).

[13] International Agency for Research on Cancer. Globocan 2008. Lyon, IARC Press, 2010.

[14] Anderson BO et al. Guideline implementation for breast healthcare in low-income and middle-income countries. Overview of the Breast Health Global Initiative Global Summit, 2007. Cancer, 2008, 113 (Suppl): 2221-2243.

[15] URL: WWW.com./ breast-self-exam.htm assessed on $27 / 12 / 2012$.

[16] Park, J. E. \& park Text book of preventive and Social Medicine. Jabalpur: M/S BanarsidesBhanot Publishers; 2002.

[17] Budden Lea, Young Women's Breast Self-Examination knowledge and Practices, Journal of Community Health Nursing, 1995, Vol-12 (1).

[18] Janda M, obermair A. G, Waldhoer T, Vutuc C, A study conducted on knowledge and attitude regarding breast selfexamination, j cancer educ. 2000 summer; 15 (2): 91-4.

[19] Milaat WA., A study conducted on knowledge regarding breast self-examination and breast cancer, department of community medicine, college of medicine, king abdulaziz university, Jeddah, Saudi Arabia. East Mediterr Health j. 2000 Mar-May; 6 (2-3): 338-44.

[20] Benjamin O. Anderson, Susan Braun, Susan Lim, Robert A. Smith, Stephen Taplin and etal.: Early detection of breast cancer in countries with limited resources. The breast Journal 2003, 9 (suppl.): S51-S59.

[21] Delecar men MG, Hughes. KS, Halpern E, etal. Racial different in mammographic breast density cancer 2003, 98 (3): 590-996, 1.

[22] Baxter, N. Preventive health care, 2001 up to date: should women routinely thought BSE to screen for breast cancer? Can. med. Asso. J. 164 (13) 1837-1846, 2001.

[23] URL: WWW.Google.com./int/breast-selfexam.cfm.htm/publications/catalogue.pdf.Assessed on December 25/12/2012.

[24] URL: http://www.who.int/breast-self-exam.cfm.htm/ publications/catalogue.pdf. Assessed on Februry 22.2005. 